\title{
Symptomatic hyponatremia during the diabetic ketoacidosis in 5 years old child with new onset diabetes - own experience
}

Objawowa hiponatremia w przebiegu kwasicy ketonowej u 5-letniego dziecka z nowo rozpoznaną cukrzycą - doświadczenia własne

\section{${ }^{1}$ Anna Kącka, ${ }^{1}$ Agnieszka Banach, ${ }^{1}$ Jolanta Jabłońska, ${ }^{1}$ Dorota Charemska, ${ }^{1}$ Bożenna Klonowska, ${ }^{2}$ Barbara Głowińska-Olszewska}

${ }^{1}$ Department of Clinical Pediatrics, Faculty of Medical Sciences, University of Warmia and Mazury in Olsztyn, Provincial Specialist Children's Hospital, Olsztyn, Poland ${ }^{2}$ Department of Pediatrics, Endocrinology, Diabetology with Cardiology Division, Medical University of Bialystok, Poland

\begin{abstract}
Hyponatremia is the one of the most common electrolyte abnormality in the clinical practice and is associated with increased morbidity and mortality. Decreased serum sodium levels are occasionally observed in patients with diabetes mellitus, especially in those, who present with the diabetic ketoacidosis. It can develop at the each stage of a treatment, as a complication of hyperglycemia and intensity of the therapy, but also the other underlying causes should be consider. In this report we present a patient with symptomatic hyponatremia in the new diagnosed patient with type 1 diabetes mellitus.
\end{abstract}

Key words:

hyponatremia, diabetes mellitus, diabetic ketoacidosis, syndrome of inappropriate antidiuretic hormone hypersecretion (SIADH).

\section{Streszczenie}

Hiponatremia jest jednym z najczęstszych zaburzeń elektrolitowych w praktyce klinicznej i wiąże się ze zwiększonym ryzykiem wystąpienia powikłań oraz zwiększoną śmiertelnością. Zmniejszone stężenie sodu w surowicy obserwuje się u pacjentów chorych na cukrzycę, szczególnie w przebiegu kwasicy ketonowej. Może ono wystąpić na różnych etapach leczenia jako powikłanie hiperglikemii i intensywności terapii, jednakże przy diagnostyce różnicowej powinny zostać wzięte pod uwagę inne przyczyny. W artykule przedstawiono przypadek objawowej hiponatremii u pacjenta z nowo rozpoznaną cukrzycą typu 1.

Słowa kluczowe:

hiponatremia, cukrzyca typu 1, kwasica ketonowa, zespół nieadekwatnego wydzielania wazopresyny (SIADH). 


\section{Introduction}

Hyponatremia is the one of the most common electrolyte abnormality in the clinical practice and is associated with increased morbidity and mortality.

Decreased serum sodium levels are occasionally observed in patients with diabetes mellitus, especially in those, who present with diabetic ketoacidosis and can be attributed to numerous underlying pathogenetic mechanisms. [1]

Diabetic ketoacidosis (DKA) results from deficiency of circulating insulin and increased levels of the counterregulatory hormones (catecholamines, glucagon, cortisol, growth hormone). It is characterized by severe depletion of water and electrolytes from both the intra- and extracellular fluid compartments. Frequencies range from approximately $15 \%$ to $70 \%$ in Europe and North America at the diabetes type 1 onset, while in children with established disease, is $1 \%$ to $10 \%$ per patient per year. The proper therapy can prevent development of the complications. Some of them are related to the DKA itself, while the others might be unfortunately iatrogenic. The most commonly seen are: hypoglycemia, hyperglycemia, hypokalemia, hyperkalemia, hyponatremia, hypernatremia, hypovolemic shock, acute kidney failure. Neurological complications including brain oedema, venous thrombosis and others like rhabdomyolysis, gastrointestinal bleeding, sepsis, disseminated intravascular coagulation are less frequent [2].

Hyponatremia seen in the DKA can be differentiate based on the direct measurement of plasma osmolality (Posm) between hypotonic (with decreased Posm) and associated with normal or even increased tonicity.

In the course of DKA marked hyperglycemia leads to increased Posm frequently in the range of 300 to $350 \mathrm{mmol} / \mathrm{kg}$ and glucose, largely restricted to the extracellular space, causes osmotic movement of water into the extra- cellular space thereby causing dilution hyponatremia. Once the osmotic diuresis rises, the hypotonic hyponatremia can be noted. Moreover the excretion of -hydroxybutyrate and acetoacetate obligate urine sodium losses resulting in aggravation of hypovolemia and decreased Posm [3].

Recent studies also revealed that the osmoregulation of arginine vasopressin (AVP) is altered and its plasma concentration is increased in DKA $[4,5]$.

The aim of this report is to present own experience with symptomatic hyponatremia in the new diagnosed patient with diabetes mellitus type 1.

\section{Case presentation}

Patient JC, male, 5.2-years-old. Born from $3^{\text {rd }}$ pregnancy, in $39 \mathrm{Hbd}$, with body weight $3340 \mathrm{~g}$, in good general condition (Apgar 10). In the $2^{\text {nd }}$ month of life hospitalized due to pneumonia, urinary tract infection and hyponatremia, with the final diagnosis based on the urine steroid profile - pseudohypoaldosteronism. Since then no further episodes of hypo- natremia has been noted. Otherwise healthy. Admitted to the Endocrinological Ward with the history of polyuria, nycturia in the past month. On physical examination - generally unwell, apathetic, but with logical contact, decreased skin turgor, dry mucous, capillary refill time $4-5$ seconds, heart rate 112/min, blood pressure (BP) 112/74 mm Hg, oxygen saturation 95\%. In the laboratory test hyperglycemia, compensated metabolic acidosis were present, $\mathrm{HbA}_{1 \mathrm{C}}-9,9 \%$. Intravenous fluids $(0,9 \%$ $\mathrm{NaCl}$, followed by $5 \%$ glucose combined with $0,9 \% \mathrm{NaCl}$ ) and intravenous insulin with potassium supplementation (two hours after initial hydration) were started. Normoglycemia was achieved after 6 hours of treatment. In the next 36 hours patient started to complain about abdominal pain, vomited 3 times, no fever, normal vital signs, glucose levels maintain in the range between 156-166 mg/dl. Intravenous insulin therapy and fluids were continued. In the 42 hour from admission sudden lost of consciousness and generalized tonic - clonic seizures were observed, stopped by diazepam given per rectum. In the laboratory test - hyponatremia was detected, with decreased plasma osmolality, increased urine osmolality and increased urine sodium concentration. ACTH, cortisol level, liver function test, kidney function test, thyroid function test, lipid profile were normal. Aldosterone concertation was raised with decreased renin activity.

CT of the head didn't reveal any abnormalities. On physical examination there were no signs of dehydration and blood pressure maintained stable. Treatment with $3 \% \mathrm{NaCl}$ and hydrocortisone (HCT) intravenously was introduced, together with fluid restriction, intravenous insulin therapy maintained. After 12 hours normonatremia was established. The therapy with $3 \% \mathrm{NaCl}$ infusion was discontinued and intravenous insulin was replaced by subcutaneous long-acting and rapid acting insulin. Hydrocortisone intravenously has been continued for the following 3 days - with gradual reduction of the does. Due to relapse of mild hyponatremia, he was kept on fluid restriction and oral sodium chloride (kitchen salt $3 \mathrm{~g}$ per day in divided portion) was given to the food for the next 4 days. In the control laboratory test after 10 days from the first presentation of the hyponatremia $-\mathrm{Na}$, POsm, urinary steroid profile analysis using GC-MS, aldosterone, renin, TSH, fT4 - were normal and 21-hydroxylase antibodies were negative. Unfortunately AVP was checked for the very first time at that stage and was decreased (3,5 ng/l, $N<8)$. Additionally, DM1 was confirmed with positive antibodies: anti-GAD, IA2 and low C-peptide. Ultrasound of the abdomen showed no abnormalities and in ECHO - PFO was reported. Patient was discharged home in general well state on normal fluid intake without sodium chloride supplementation.

After one month he was admitted for elective MRI of the pituitary gland where no abnormalities were reported and laboratory tests including $\mathrm{Na}, \mathrm{K}, \mathrm{Cl}, \mathrm{PO}$ m, morning cortisol were in the normal range (Tables I, II).

Currently the patient has been treated for T1DM for over a year under the Diabetology Outpatient Clinic with insulin pump and no episodes of hyponatremia were reported. 
Table I. Changes in electrolytes levels, ph and glucose levels in the patient

\begin{tabular}{|c|c|c|c|c|c|c|c|}
\hline Time & $\begin{array}{l}\text { Glucose } \\
\text { level } \\
(\mathrm{mg} / \mathrm{dl})\end{array}$ & $\begin{array}{l}\mathrm{Ph} \\
(7,35-7,45)\end{array}$ & $\begin{array}{l}\mathrm{HCO} 3 \\
(\mathrm{mmol} / \mathrm{l}) \\
(21-25)\end{array}$ & $\begin{array}{l}\mathrm{BE} \\
(\mathrm{mmol} / \mathrm{l}) \\
(-2,5-2,5)\end{array}$ & $\begin{array}{l}\mathrm{Na} \\
(\mathrm{mmol} / \mathrm{l}) \\
(132-141)\end{array}$ & $\begin{array}{l}\mathrm{K}(\mathrm{mmo} / \mathrm{l}) \\
(3,2-5,7)\end{array}$ & $\begin{array}{l}\mathrm{Cl}(\mathrm{mmol}) \\
(98-107)\end{array}$ \\
\hline Admission: & 334.4 & 7.38 & 18.8 & -7.8 & 136 & 4.5 & 100 \\
\hline 12 hours after the admission & 167 & 7.39 & 20.2 & -5.9 & 132 & 4.1 & 102 \\
\hline 42 hours after the admission & 126 & 7.42 & 21.3 & -4.6 & 117 & 3.7 & 86 \\
\hline 2 days after the admission & 184 & 7.44 & 21.1 & -5.2 & 125 & 3.7 & 93 \\
\hline 2.5 days from the admission & 94 & 7.47 & 24.6 & 0.0 & 130 & 4.0 & 98 \\
\hline 3 days after the admission & 102 & - & - & - & 133 & 3.4 & 102 \\
\hline 3.5 days after the admission & 121 & 7.43 & 24.6 & 0.1 & 138 & 3.2 & 104 \\
\hline 4 days after the admission & 158 & - & - & - & 136 & 4.1 & 100 \\
\hline 5.5 days the admission & 142 & 7.47 & 27.4 & 3.0 & 129 & 4.9 & 94 \\
\hline 7.5 days after the admission & 139 & 7.44 & 25.6 & 1.0 & 134 & 4.9 & 100 \\
\hline 10 days after the admission & 117 & 7.43 & 24.7 & -0.2 & 137 & 4.7 & 103 \\
\hline $\begin{array}{l}\text { One month from the } \\
\text { presentation of the DKA }\end{array}$ & 130 & 7.39 & 21.9 & -3.2 & 135 & 4.3 & 102 \\
\hline
\end{tabular}

Table II. Patient plasma and urine osmolality

\begin{tabular}{llll}
\hline Time & $\begin{array}{l}\text { POsm }(\mathrm{mOsm} / \mathrm{kg}) \\
(280-300)\end{array}$ & $\begin{array}{l}\text { UOsm }(\mathrm{mOsm} / \mathrm{kg}) \\
(50-1400)\end{array}$ & $\begin{array}{l}\text { UNa }(\mathrm{mmol} / \mathrm{l}) \\
(54-190)\end{array}$ \\
\hline 42 hours from the admission & 261 & 739 & 68 \\
\hline 2.5 days from the admission & 262 & & \\
\hline 10.5 days from the admission & 287 & & \\
\hline One month from the presentation of the DKA & 288 & \\
\hline
\end{tabular}

\section{Discussion}

Hyponatremia is common electrolyte abnormality encountered in children, leading in the most serious cases to hyponatremic encephalopathy. The clinical features are headache, nausea, vomiting, seizures, resulting from the brain oedema. Early diagnosis, differential between acute vs. chronic hyponatremia and introduction the optimal treatment can prevent developing cerebral demyelination and lethal outcome [7, 8]. The presented case shows how sudden and severe might be the course of hyponatremia together with the diagnostic dif- ficulties. Despite the initial normal levels of sodium, proper hydration and insulin therapy which allowed to achieve normoglycemia, patient developed hyponatremia. That inclined us to look for other causes than those related to diabetes mellitus. Hypothyrodism, kidney, liver and heart failure were excluded. In the differential diagnosis adrenal insufficiency, pseudohypoaldosteronism and SIADH were taken under the consideration [6]. With the patient history of transient pseudhypoaldosteronism the diagnosis was also review. Pseudohypoaldosteronism defines the state characterized by renal tubular unresponsiveness to aldosterone. Genetically caused 
primary (type 1 and type 2) and transient secondary forms exist. Secondary PHA is a transient aldosterone resistance condition mostly occurring in relation with urinary tract infection and/or malformations and its laboratory characteristics are similar to primary PHA. Clinical presentation includes hyponatremia, dehydration, hyperkaliemia, acidosis, increased aldosteron and renin activity. Diagnosis is confirmed based on the urine steroid profile. Noted elevation of the aldosteron and decreased renin in the presented case, seems to be secondary response to the hyponatremia, what can be supported by the fact that they went back to normal after correction of the sodium level [7].

Adrenal insufficiency might has a broad spectrum of underlying causes. In this case the most likely diagnosis were considered, including congenital adrenal hyperplasia, secondary adrenal insufficiency and Addison's disease. Normal levels of the cortisol, ACTH, the urine steroid profile and negative antibodies against adrenal cortex allowed to exclude disorders related to the disturbed production of the steroids [8].

Syndrome of inappropriate antidiuretic hormone secretion (SIADH) is defined by the hyponatremia and plasma hypoosmolality ( $<275 \mathrm{mOsm} / \mathrm{kg} \mathrm{H} \mathrm{H}_{2} \mathrm{O}$ ), UOsm above $100 \mathrm{mOsm} / \mathrm{kg}$ $\mathrm{H}_{2} \mathrm{O}$, high urine sodium above $40 \mathrm{mmol} / \mathrm{l}$, resulting from inappropriate, continued secretion or action of the antidiuretic hormone arginine vasopressin (AVP) despite normal or increased

\section{References}

1. Liamis G, Tsimihodimos V, Elisaf M. Hyponatremia in Diabetes Mellitus: Clues to Diagnosis and Treatment. J Diabetes Metab 2015; 6 : 560. doi:10.4172/2155-6156.1000560

2. International Society for Pediatric and Adolescent Diabetes (ISPAD). Clinical practice Consensus Guidelines 2018. Available at: https://www.ispad.org/page/Guidelines2018Chap11 (22.01.2019).

3. Ciechanowska M, Starzyk J. Kwasica ketonowa w przebiegu cukrzycy typu 1 u dzieci. Rozpoznanie i leczenie chorego w pierwszej dobie hospitalizacji. Endokrynol Otył Zab Przem Mat 2009; 5: 28-35.

4. Durr JA, Hoffman WH, Hensen J, et al. Osmoregulation of vasopressin in diabetic ketoacidosis. Am J Physiol 1990; 259 (5 Pt 1): E723-E728.

5. Walsh $\mathrm{CH}$, Baylis PH, Malins JM. Plasma Arginine Vasopressin in Diabetic Ketoacidosis. Diabetologia 1979; 16: 93-96.

6. Zieg J. Pathophysiology of hyponatremia in children. Front Pediatr 2017; 5: 213. doi: 10.3389/fped.2017.00213 plasma volume, which results in impaired water excretion. All of mentioned above were met in this case. Patient also respond well to the restriction of the fluids and oral supplementation of the sodium chloride [9].

No further treatment has been required and relapses has been observed [10].

\section{Conclusions}

Symptomatic hyponatremia is not a common complication seen in patients with diabetes mellitus, even during the DKA. It can develop at each stage of treatment, as a complication of hyperglycemia and intensity of the therapy, but also the other underlying causes should be considered and excluded. Making the proper diagnosis helps predict the clinical course and guide the most appropriate management.

In presented case hyponatremia occurred for the first time during the infections (urinary tract infection and pneumonia) and for the second time after the episode of mild DKA. Despite those periods, patient maintains normal plasma sodium level and doesn't require any treatment. Based on that, we recommended the routine control of the electrolytes levels and also during the course of the acute diseases or occurrence of the signs and symptoms of hyponatremia.
7. Moritz ML, Ayus JC. New aspects in the pathogenesis, prevention, and treatment of hyponatremic encephalopathy in children. Pediatr Nephrol 2010; 25: 1225-1238. doi:10.1007/s00467-009-1323-6

8. Dineen R, Thompson CHJ, Sherlock M. Hyponatraemia - presentations and management. Clinical Medicine 2017; 3: 263-269. doi: 10.7861/clinmedicine.17-3-263.

9. Korkut S, Akin L, Hatipoglu N, et al. A potential serious complication in infants with congenital obstructive uropathy: Secondary pseudohypoaldosteronism. J Pak Med Assoc 2019; 69: 108-112.

10. Kirkgoz T, Guran T. Primary adrenal insufficiency in children: Diagnosis and management. Best Pract Res Clin Endocrinol Metab 2018; 32: 397-424. doi: 10.1016/j.beem.2018.05.010

11. Thomas CP. Syndrome of Inappropriate Antidiuretic Hormone Secretion Medication. Available at: https://emedicine.medscape. com/article/246650-medication (22.01.2019).

12. Gross P. Clinical management of SIADH. Ther Adv Endocrinol Metab 2012; 3: 61-73. doi: 10.1177/2042018812437561. 